A N N A LE S

UNIVER S T A T IS MARIAE CURIE-SKŁODOW S A LUBLIN - POLONIA

VOL. XXVIII, 2

SECTIO J

2015

Ivan Franko Drohobych State Teacher Training University, Ukraine

\title{
OLENA HALIAN
}

olena.halian@gmail.com

\section{The Theoretical Basis for the Development of the Concept "Agency of the Personality of a Pupil" at the Crossroads of Ukrainian, Polish and Russian Scientific Traditions}

Teoretyczne zasady kształtowania kategorii „podmiotowość osobowości ucznia” w ukraińskiej, polskiej i rosyjskiej tradycji naukowej

\begin{abstract}
SUMMARY
The article analyzes the outlook and theoretical and methodological approaches to the analysis of the category of "agency of the personality of a pupil". The author has identified similarities and differences in scientific research of Ukrainian, Polish and Russian scholars after analysing their views. It is indicated that they share an understanding of the importance of personality approach to the educational process. In this context, the views of Ukrainian, Polish and Russian researchers differ only in the directions of scientific research. It is found out that Polish scholars give considerable attention to applied aspects of the formation of agency of the personality of a pupil, except the analysis of the theoretical and methodological issues. Ukrainian scholars have a tendency to combine theoretical and methodological approaches towards the study of an agent nature of a person with the development of new educational technologies. Psycho-pedagogical orientation of the scientific research of Russian scientists makes it possible to provide the methodological basis for the development of a new educational paradigm.
\end{abstract}

Keywords: agent; agency of the personality of a pupil; agency-developmental approach; scientific tradition

\section{INTRODUCTION}

In the situation of modernization of different spheres of public life there arise new requirements for a person who can not only adapt to changing conditions, but actively act to transform the surrounding reality. This reflects the attitude of 
the personality as an agent in life, but does not reveal the whole complex system of internal determinants of the origin of their agent position. In this regard, the scientific revolution introduced the category of "agency", which became the basis for interpretation of activity and/or "existential" levels of human life. Its interdisciplinary nature points to a comprehensive approach to the identification of the essential features actively converting individual attitude to oneself, others and reality, the display of its factors and conditions. The analysis of the interaction between education and personal development becomes particularly relevant to the study of agency.

Understanding the importance of the processes of education, upbringing and development makes it possible to consider agency of the personality of a pupil to be the focal point of modern education. One of its tasks is to create conditions so that pupils could realize their personal potential. Basic principles for agency development are presented in the system of the humanitarian educational paradigm. Its theoretical and methodological principles reflect new approaches to identifying aims in education. I believe that this implies the importance to be aware of one's own life purpose (personality-value component), a holistic view of the world and oneself with a focus on the process of understanding the nature of knowledge, a new type of relationship to knowledge (cognitive-personal component), the development of a humanitarian quality of the personality, the capacity for dialogue in the process of educational interaction (personal-communicative component). All these components of a humanitarian tendency of education were elaborated in the system of a prior humanistic pedagogical tradition. Thus, they are partly presented within the framework of modern educational process which a priori indicates an active, agent nature of a pupil, their autonomy and creativity in learning. However, this approach to education is often only declared and it is extremely difficult to implement it in practice of pedagogical interaction.

The need for scientific analysis of the agency of a pupil is confirmed by a number of contradictions that have arisen from implementing an agency-based approach in the educational process at school. These are:

- the need to optimize the educational situation based on empowering pupils to acquire agent experience and the real practice of education and upbringing,

- the need to introduce a humanitarian didactic approach to the content of textbooks and difficulty of its implementation in a certain system of knowledge,

- the importance of changing schemes of thinking while considering the educational situation and insufficiently grounded theoretical and methodological foundations for the analysis of the phenomenon "agency of the personality of a pupil" in educational research programs. 
Nowadays school should become the centre of agency development in pupils. Due to understanding and awareness of the significance of raising children as active, self-sufficient and unique individuals, shaping their personal world views based on the shift in the approach to learning, creating a situation of complicity in teacher-pupil interaction in order to fulfil their own potential, we can optimize the educational situation in modern school.

The need for modification of approaches to the educational process at school highlights the need to specify a methodological basis that contributes to a better understanding of the conceptual features of "agency". Through theoretical substantiation of the issues which form the basis for the analysis of this scientific construct, there is a possibility to give arguments for innovative approaches to educational content and practice of the pupil's agent position in education. Analysis of the approaches to agency development in Ukrainian, Russian and Polish educational traditions provides prospects for deepening and strengthening methodological principles concerning optimization of school education space.

\section{URGENT ISSUES CONCERNING STUDYING THE AGENCY OF THE PERSONALITY OF A PUPIL IN VIEWS OF UKRAINIAN, POLISH AND RUSSIAN SCHOLARS}

The category of agency has emerged in pedagogical studies due to the necessity for the analysis of the position of a pupil in the system of a humanized pedagogical interaction and a new outlook on his/her role in the process of cognition. Personal significance of information, creating new meanings while acquiring knowledge, personal self-development as a result of educational activities promoted differentiation of ideas about the agent nature of the personality. In this regard, along with the use of concepts "an agent", "agent position", "agency-based interaction", the phenomenon of "agency" was introduced in pedagogy from psychology and philosophy. Its use is associated with the necessity for isolating the new status of the personality and ideas about determinism and its manifestations.

First profound research of agency as an educational category dates back to late 80 s and early 90 s of the $20^{\text {th }}$ century, first of all in Polish academic school (Gurycka 1989; Ruciński 1993; Zaciński 1986; and others). Though the work by Matiaszkowaja Podmiotowość w nauczaniu i wychowaniu albo wspólny udziat $i$ odpowiedzialność, that dates back to 1985, was mentioned in the research by Hurlo (2003). And in common past of Ukraine and Russia - Soviet psychology and philosophy - the development of the agent essence of man associates with the $20 \mathrm{~s}$ of the $20^{\text {th }}$ century and the research by Rubinshtejn (according to: Tatenko 1996). At the end of the $20^{\text {th }}$ century Ukrainian and Russian scholars were actively investigating the issue of philosophical and psychological foundations of the agent nature of the personality (Petrovskij 1996; Tatenko 1996; and others). At the 
same time scholars identify prospects of taking into account the above mentioned peculiarities of analysing the personality in conditions of the educational process (Beh 1997).

The change in the socio-political situation in the countries, academic achievements of which is being analyzed, the development of democratic tendencies at this time opens up the possibility to introduce ideas related to the humanization of education, focus on agency-based interaction, educative dialogue. In this regard it should be noted that the end of the $20^{\text {th }}$ century was a significant milestone in providing a scientific basis for viewing a pupil as a personality with individual characteristics, abilities and opportunities. Humanistic paradigm with its orientation to the personality became a methodological basis for trying to find new educational technologies. However, humanistic understanding of the goals of education only identified the need for restructuring the educational process. Despite the progressive approach, in most cases the agent position of a pupil was declared, but not really defined.

The beginning of the $21^{\text {st }}$ century was marked by a growing interest in the personality of man, in his/her life and so again the research of agency was highlighted by representatives of the countries surveyed (Borytko 2000; Górska 2008; Halyan 2015; Mieszalski 2005; Ol'hovaja 2005; Slastjonin 2006; Stasiak 2006; Volkova 2012). Scientific issues of creating meanings and world outlook of the personality, shaping his/her own world views became urgent, and, respectively, values and holistic attitude to a person were of great importance, especially in the educational process. These trends correspond to the humanitarian educational paradigm in which agency of a pupil is a priority.

However, analysing of the concept of "agency of the personality of a pupil", we should first identify and understand the essential characteristics of the concept of agency. Only this approach will ensure a fundamental nature of the proposed statements and will outline tendencies of their implementation in educational practice. And this determines the need to analyze the philosophical and psychological nature of the phenomenon under study as an ideological basis for scientific research (the term "agency" emerged within psychology, but it has become interdisciplinary).

Active nature of man is the primary meaning of the notion of an agent. For centuries, its meaning and interpretation evolved depending on the dominant worldviews of great thinkers, philosophers. The transition from scientific substantiation of contrasting the subject and the object in clearly defined characteristics (classical philosophy) towards levelling the differences in contemporary philosophical discourse (postmodernism) indicates the expansion of traditional approaches of scientific analysis, which leads, according to the Russian researcher Os'mina, to blurring the semantic context of the term "agent" and its derivatives (Os'mina 2012). Nevertheless, the categorical status of the agent indicates its 
leading position in assessing manifestations of the personality in terms of their structure, dynamics and regulation (Znakov 2003) and serves as the basis for identifying the semantic content of the category of agency.

The first problem which is detected during the scientific analysis of this phenomenon is related to the definition of its nature in relation to the concept "identity".

The proposed definitions of agency imply its existence as a person's characteristic (Volkova 2012), ability (Halyan 2015; Kadzhaspirova, Kadzhaspirov 2005; Stasiak 2006), disposition (Tatenko 1996), personal formation (Borytko 2000; Hurlo 2003; Petrovskij, Jaroszewskij 2001). This diversity of approaches makes it difficult to develop a theoretical construct "agency" and cause difficulties in identification of its attributes. An indication of the place of agency in the structure of the personality, at the same time, reflects the authors' vision of the nature of this phenomenon (congenital, acquired, formed). These peculiarities of the authors' scientific views, respectively, reflect the determination, conditions of the development of the agent nature of the personality, stages of its formation and so on. In this context, we turn to the analysis of the activity and the existential approaches to the interpretation of agent characteristics of the personality.

The former one covers the potential through a variety of activities and their assimilation to form an agent attitude to reality and oneself, to develop the ability to plan activities, to foresee the results, to implement plans, to correct failures. This is a clear separation of subjective and objective reality. Agency of the personality develops on the verge of an objective and subjective world, which corresponds to the model of agency developed by the Russian researcher Thostov (according to: Sergienko 2012). In this context it is advisable to use the concepts "agent of activity", "agent of cognition", "agent of communication", "agent of work". The Ukrainian researcher Antonova considers pupils' agency, for example in learning, as "perceived regulatory activity of the agent in cognition, directed to an independent search for the problem" (Antonova 2009, p. 242), giving priority to intellectual factors of agency over volitional and emotional ones. Activity context of agency is represented in views of the Polish scholar Stasiak (2006). In his view, man is able to act consciously and creatively, improving his/her own personality dispositions and creatively solving the problems, and agent organization of training will contribute to personal development.

The analysis of the agent-existential approach involves identifying the agent nature of man through his/her experiences, emotions, values and meaningful value-semantic formations that determine a tendency towards discovering oneself in the world, orientation points of one's self-realization, self-fulfilment. In this regard Os'mina indicates that agency is primarily experienced, but not demonstrated, and that is why we observe a convergence of objective and subjective reality (Os'mina 2012). In this case agency is analyzed in terms of 
"experience", "an agent of creating meanings", "an agent of development" and reflects the values and motivation (semantic) attitude of a person to him/herself and the world.

Differentiation and contrasting these approaches are methodologically grounded but not reasonable. In this regard, I support the Polish researcher Hurlo as to the way of agency formation: "[...] from the formation of agency of a pupil as an agent of educational activities to the formation of individuality as a whole" (Hurlo 2003, p. 14). Activity descriptions and existential descriptions of the nature of agency are presented as a single process of the development of a person's agent nature in time and space of his/her life.

The combination of the agent-activity and the agent-existential approaches creates an ideological basis for intensifying the process of agency formation in a pupil in educational space. Providing a methodological basis for modern pedagogy, they determine possibilities for implementing an agent potential of the individual pupil (agent orientation), but not just acquisition of knowledge and skills (cognitive orientation). This involves changing a conceptual approach to the practice of education, upbringing and development of pupils, orientation of educational space to individual development of its agents.

Apart from this, we should pay attention to one fact: agency of the individual is not a constant formation. It develops, acquires modified forms, and gradually its system of determination reorients in the process of socialization and individualization (from external motivation to internally specified positions). Hence, considering agency at various stages of ontogenesis, those theories that point to its ontogenetic aspect are of primary importance. This is the level and the stages of the agent nature of man highlighted by the Ukrainian researchers Tatenko (1996), Maksymenko (2006) and Beh (1997), and the Russian scientists Ol'hovaja (2005), Petrovskij (1996) and Volkova (2012). According to the Polish researcher Hurlo "agency has properties of plasticity, dynamics and variability" (Hurlo 2003, p. 14).

\section{MAIN ISSUES THAT CONSOLIDATE THE IDEA OF AGENCY OF THE PERSONALITY OF A PUPIL IN VIEWS OF UKRAINIAN, POLISH AND RUSSIAN SCHOLARS}

The analysed authors' approaches to the interpretation of the content of agency cause difficulties in identifying criterion-referenced approaches to its basic characteristics, factors and conditions of its development. Therefore, we have attempted to identify those issues that reveal the agent nature of the personality of a pupil, which is a generalization of scientific research conducted by Ukrainian, Polish and Russian scholars. They reflect a holistic vision of agency in personal, 
behavioural and cognitive dimensions. In this situation, agency of the personality of a pupil is an integral formation that is developed in the system of interactive, agency-based teacher-pupil interaction.

1. A pupil is an agent of education, upbringing and development. In the context of this thesis we get an idea of a pupil as a certain reality that exists, displays his/her attitude, acquires knowledge, reflects internalized values, meanings, goals, aspirations and motives in his/her behaviour. His/her agent manifestations do not occur by themselves, but under the influence of significant Others (teachers, parents, trustworthy friends, etc.), as a result of providing a specially-organized educational space (personality-oriented: Beh 1997; personality-developing: Jakimanskaja 1996; agent-developing: Petrovskij 1996), which ensures the formation of attitude towards oneself as an active person. Active assimilation of social experience, combined with their acquired experience creates conditions for considering a pupil as an agent of the educational process.

2. A pupil is characterized by the intentional need for activity. This intentionality is produced by the personality's desires, intentions, beliefs, goals, and therefore may be unconscious or conscious. Its manifestation is connected with the initiative of the personality. In the system of education agency is presented as a conscious intention of a pupil to implement a plan, action, to express an opinion, ask, put forward a supposition, identify the problem and solve it and so on. The Polish researcher Stasiak thinks that the desire to act, perseverance in action is one of the manifestations of agency (Stasiak 2006).

3. Activity of a pupil manifests itself in "appropriation" (assimilation), understanding and transformation of objective reality and oneself. In our view, in this case activity is not an attribute of agency, as it is indicated by most scholars, but a systemically important unit that defines functioning of each of the attributes of agency. Studying its structural and semantic model, I have assumed that the leading place among them belongs to "initiative, independence, creativity, responsibility, freedom” (Halyan 2015, p. 61).

4. The spheres of agency manifestations are educational (cognitive) activities, interaction with others, activities of social utility, self-cognition. Thus, a pupil is able to exercise self-education, self-upbringing, self-development, self-cognition, self-fulfilment. In my view, in this context agency is defined by the ability of pupils to realize their own goals, to overcome the contradictions in the images of a real self and a perfect self, use their capacity for achieving educational and life goals, change themselves and the world and so on.

5. Agency of a pupil has different manifestations. They are caused by mental organization of man: by the system of dominating motives (orientation), abilities and inclinations, temperamental characteristics, interests and values and others. So, in this context agency points to a unique inner world of the personality of a pupil, his/her individuality (homo unicum). In my view, an individual approach 
in the process of education and upbringing will provide formally dynamic (individual) and subject-content (personality) characteristics of the personality of a pupil.

6. At the level of the educational process a pupil as an agent, as a source of causality of existence (Rubinshtejn 2000), does not only sets the beginning of the causal series, but can perceive oneself as the cause of what he/she does ("I can do it", "I want to do it", "I'm doing it"). The abovementioned is based on the theory of self-causality developed by the Russian scientist Petrovskij. He believes that "to be a personality" means to be an agent of oneself, one's existence in the world, a bearer of the idea of "Self" as the cause of oneself (the idea of "causa sui"; Petrovskij, Jaroszewskij 2001, p. 227). Self-awareness gives significance to one's own activity, which is directed by intentions and has a particular result. The pupil's awareness of one's own agency becomes an additional source of self-awareness. According to the Polish researcher Jarymowicz, reflexivity plays an important role in this process (Jarymowicz 2008).

7. The complex processes of modernization of education, in addition to organizational and educational, didactic, methodical issues, should include a reference to the need for a change in the position of the teacher in the educational process (Bałachowicz 2009; Borytko 2000; Hurlo 2006; Petrovskij 1996; and others). The teacher's role in the development of pupils' agency requires a transition from dominance and regulation to support and maintenance. As it is pointed out by the Russian psychologist Petrovskij, agent-developmental education creates conditions for a child to manifest and experience his/her own agency (Petrovskij 1996). The basis of pedagogical orientation of teachers should be valuable and integral relationship with pupils (axio-educational guides of educational activities). But the teacher must become a "significant Other". Only in this case we will strengthen agent characteristics of pupils. For this purpose a dialogic approach is introduced in the organization of the educational process. Making teacher-pupil relationships dialogic opens up opportunities for the development of agency in pupils, giving personal meaning to educational interaction, ensuring partnership, in which human centeredness of the educational environment is being implemented.

8. In addition to agent-developing educational environment, personality-oriented educational technologies, the introduction of advanced educational theories and educational paradigms, an essential tool of developing pupils' agency is their learning activities. Their developmental potential is ensured by those new qualities (a new type of attitude to oneself, to education and a school subject), which is a direct result of the learning process. Acquisition of learning activities (the ability to learn), its effectiveness, giving personal meaning to knowledge are viewed as indicators of actualization of agent manifestations of a pupil and they ensure his/ her self-development and self-fulfilment. 


\section{CONCLUSIONS}

Progressive trends of the $20^{\text {th }}$ century in the field of science and technology led to an increased interest in the possibilities of a person to be an agent of activity, cognition and one's own life. In this regard, along with the category of an agent, scientific research of the end of the $20^{\text {th }}$ century witnessed an active use of the concept of agency. Its categorical status was defined by the scientific substantiation of the need to consider a person as an individual and a unique personality. It was stated that in the process of socialization a person does not only cognizes the world, but interprets it according to his/her own vision, expresses a significant individual attitude to it, and alters reality and him/herself. In this context agency becomes a potential and/or implemented ability to demonstrate an intentional need for activity in different areas of life.

This approach to the personality identified an important task of the educational environment - the formation of agency in a pupil. This, in turn, determined the need to scientifically substantiate the essence of the concept "agency of a pupil", its attributive characteristics and identify conditions and ways of implementing the agent nature of the personality in education and upbringing.

The views of Ukrainian, Polish and Russian scholars reflect the main tendencies in scientific research. Analysis of their findings makes it possible to state that a consolidating element for them is awareness of the importance of creating a developmental educational environment filled with meaningful information and opportunities for a creative approach to developing necessary competences. In addition, these scientists focus on the need for teachers to understand their role in the formation of agency in pupils. And this requires a change in the teacher's professional position as well as learning new ways, methods, and techniques of educational activities.

At the same time it is necessary to pay attention to what is different in scientific research of scholars from different countries. These are not fundamental differences, but only priority directions in the analysis of the category "agency" as to various aspects of the personality's life. In this context, Polish scientists show great interest in issues of theoretical substantiation and arguments for the possibilities of the educational environment in agency development in pupils, they offer specific techniques and methods of organizing education, that contributes to enhancing pupils' agent potential. Thus, in addition to analysing theoretical and methodological foundations of agency of the personality, they pay considerable attention to the applied aspects of its formation, which are described in detail.

Ukrainian pedagogues and psychologists focus on the important nature of the concept of agency and propose to use a personality-oriented educational technology in the educational process, through which a pupil's potential is revealed and which ensures free development of the personality. This position corresponds to 
priorities in views on agency that develops. The result of scientific research in Ukrainian psycho-pedagogical tradition was continual-genetic concept of agency of the personality that is reflected in the analysis and presentation of genetic levels and stages of agency development. Consequently, Ukrainian scholars strive to combine theoretical and methodological approaches to the study of the agent human nature with the development of new educational technologies.

Findings of Russian scholars are different in profound efforts to reveal the philosophical, psychological and pedagogical principles of agency. The focus is on the methodological aspects of introduction of the category of agency into the scientific area, identification of relationships between concepts that explain the new view on activity of the personality, identification of conditions and factors of agency development. Thus, the analysis of the scientific status of the category of agency is presented in educational research of Russian scientists in the light of psychological theories and concepts. Psychological and pedagogical orientation of scientific research enables us to provide the methodological basis for the development of a new educational paradigm. Agent-activity approach is identified to be dominant in the development of the agent nature of the personality.

The presented peculiarities of the views on agency open up opportunities for expanding scientific research conducted by scholars from different countries and pooling their efforts to modernize the educational environment based on substantiated theories, conceptions and developed educational technologies.

\section{REFERENCES}

Антонова И. (2009), Субъектность как интегративное свойство обучаемости, Славянск.

Bałachowicz J. (2009), Kategoria podmiotowości jako wyznacznik przemian stylu pracy wspótczesnego nauczyciela, [w:] I. Adamek, W. Żmijewska (red.), Nauczyciel w systemie edukacyjnym teraźniejszość i przyszłość, Kraków.

Бех I. (1997), Наукові засади створення особистісно орієнтованих виховних технологій, «Початкова школа», 9.

Борытко Н. (2000), Пространство воспитания: образ бытия, Волгоград.

Хурло Л. (2003), Профессиональная подготовка учителя к развитию субъектности ученика, Калининград.

Галян О. (2015), Суб'єктність особистості школяра як інтердисииплінарна наукова проблема, «Неперервна професійна освіта: теорія і практика», 1-2 (42-43).

Górska L. (2008), Podmiot i podmiotowość w wychowaniu. Studium w perspektywie poznawczej pedagogiki integralnej, Szczecin.

Gurycka A. (red.) (1989), Podmiotowość w doświadczeniach wychowawczych dzieci i młodzieży, Warszawa.

Якиманская И. (1996), Личностно-ориентированное обучение в современной школе, Москва. Jarymowicz M. (2008), Psychologiczne podstawy podmiotowości. Szkice teoretyczne, studia empiryczne, Warszawa.

Коджаспирова Г., Коджаспиров А. (2005), Словарь по педагогике, Москва.

Максименко С. (2006), Генеза здійснення особистості, Київ. 
Mieszalski S. (2005), Interpretacje podmiotowości dziecka: kultura - szkoła - wczesna edukacja, „Problemy Wczesnej Edukacji”, 2.

Ольховая Т. (2005), Педагогический аспект проблемы развития субъектности, «Вопросы гуманитарных наук», 2 (17).

Осмина Е. (2012), Психология субъектополагающего взаимодействия, Казань.

Петровский А., Ярошевский М. (2001), Теоретическая психология, Москва.

Петровский В. (1996), Субъектность: новая парадигма в образовании, «Психологическая наука и образование», 3.

Рубинштейн С. (2000), Основы общей психологии, Санкт-Петербург.

Ruciński S. (1993), Podmiotowość z punktu widzenia pedagoga, [w:] B. Suchodolski (red.), Podmiotowość jako problem filozoficzny, społeczny i pedagogiczny, Warszawa.

Сергиенко Е. (2012), Принциипы психологии развития: современный взгляд, «Психологические исследования», 5, 24.

Сластенин В. (2006), Субъектно-деятельностный подход в общем и профессиональном образовании, «Сибирский педагогический журнал», 5.

Stasiak M. (2006), Refleksje wokół pojęcia podmiotowości, „Civitas Hominibus. Rocznik Filozoficzno-Społeczny", 1.

Татенко В. (1996), Психология в субъектном измерении, Киев.

Волкова Е. (ред.) (2012), Развитие субъектности в онтогенезе в современном соииокультурном пространстве образования и семьи, Нижний Новгород.

Zaciński B. (1986), Podmiotowość jako cel i środek wychowania, Lublin.

Знаков В. (2003), Психология субъекта как методология понимания человеческого бытия, «Психологический журнал», 24, 2.

\section{STRESZCZENIE}

Autorka artykułu poddaje analizie stanowiska światopoglądowe i podejścia teoretyczno-metodologiczne do kategorii „podmiotowość osobowości ucznia”. Na podstawie rozważań poglądów naukowców ukraińskich, polskich i rosyjskich zdefiniowano podobieństwa i różnice w kierunkach ich poszukiwań naukowych. Podkreślono, iż łączy je przywiązanie wagi do aktualności indywidualnego podejścia do organizowania procesu edukacji. W tym kontekście poglądy ukraińskich, polskich i rosyjskich badaczy różnią się jedynie kierunkami poszukiwań naukowych. Udowodniono, iż oprócz dociekania zasad teoretyczno-metodologicznych, polscy naukowcy szczególną wagę przywiązują do aspektów stosowanych w kształtowaniu podmiotowości osobowości ucznia, które są dokładnie uzasadnione i opisane. Badacze ukraińscy dążą do połączenia podejść teoretycznometodologicznych $\mathrm{w}$ badaniach istoty podmiotowej jednostki ludzkiej z wypracowaniem nowych technologii pedagogicznych. Nastawienie psychologiczno-pedagogiczne w poszukiwaniach naukowych badaczy rosyjskich ustala ramy metodologiczne dla wypracowania nowego paradygmatu edukacyjnego.

Słowa kluczowe: podmiot; podmiotowość osobowości ucznia; podejście podmiotowo-rozwojowe; tradycja naukowa 